\title{
PENGARUH CAMPURAN PELARUT AQUADES-ETANOL TERHADAP KARAKTERISTIK EKSTRAK BETASIANIN DARI KULIT BUAH NAGA MERAH (Hylocereus polyrhizus)
}

\author{
The Effect of Water-Ethanol Solvent Mixture on The Characteristics of \\ Betacyanin Extract from Red Dragon Fruit Peel (Hylocereus polyrhizus) \\ Syarifa Ramadhani Nurbaya*, Widya Dwi Rukmi Putri, Erni Sofia Murtini \\ Jurusan Teknologi Hasil Pertanian - Fakultas Teknologi Pertanian - Universitas Brawijaya \\ Jl. Veteran - Malang 65145 \\ *Penulis Korespondensi: email syarifa.04@gmail.com
}

Disubmit: 10 Agustus 2017 Direvisi: 2 Februari 2018 Diterima: 16 Agustus 2018

\begin{abstract}
ABSTRAK
Pewarna makanan alami tidak menimbulkan efek samping bagi kesehatan. Kulit buah naga merah merupakan sumber pigmen betasianin yang dapat dimanfaatkan sebagai pewarna makanan alami. Proses ekstraksi diperlukan untuk memisahkan komponen pigmen betasianin dengan komponen bahan lainnya. Ekstraksi menggunakan pelarut aquades atau etanol saja dapat menghasilkan kadar betasianin yang rendah. Menggunakan campuran pelarut aquades dengan etanol dalam proses ekstraksi bertujuan untuk memperbaiki karakteristik ekstrak. Penelitian ini menggunakan Rancangan Acak Kelompok (RAK) dengan satu faktor, yaitu rasio jenis pelarut. Jenis pelarut yang digunakan adalah aquades dan etanol dengan perbandingan 100:0, 80:20, 60:40, 40:60, 20:80, dan 0:100 (v/v). Perlakuan terbaik terdapat pada perlakuan rasio aquades dibanding etanol 20:80 (v/v) dengan karakteristik kadar betasianin $99.27 \mathrm{mg} / \mathrm{L}$, kadar pektin $0.48 \%$, nilai kecerahan (L) 35.03, nilai kemerahan $\left(\mathrm{a}^{+}\right) 49.78$, nilai kekuningan $\left(\mathrm{b}^{+}\right) 14.70$, sudut hue $14.02^{\circ}$, dan nilai viskositas $2.25 \mathrm{cP}$. Ekstrak pigmen dari kulit buah naga merah yang diekstraksi menggunakan pelarut aquades-etanol berpotensi digunakan sebagai pewarna makanan alami
\end{abstract}

Kata kunci: Betasianin; Ekstraksi; Kulit Buah Naga Merah

\begin{abstract}
Natural food coloring will not give any side effects on health. Red dragon fruit peel is source of betacyanin pigment which can be utilized as a natural food coloring. The extraction process was needed to separate betacyanin from other components. Previous study showed extraction using water or ethanol as solvent caused less betacyanin content could be extracted. This study evaluated improvement of pigment extract characteristics from red dragon fruit peel using water and ethanol mixture as solvent. This research used Randomized Block Design with solvent ratio as the only factor. Mixture of water:ethanol used in this study were consist of 100:0, 80:20, 60:40, 40:60, 20:80, and 0:100 (v/v) in ratio. The best treatment was found in the treatment of water:ethanol with ratio 20:80 (v/v). Betacyanin content in this treatment was $99.27 \mathrm{mg} / \mathrm{L}$, pectin content $0.48 \%$, brightness $(L) 35.03$, redness $\left(a^{+}\right) 49.78$, yellowness $\left(b^{+}\right) 14.70$, hue angle $14.02^{\circ}$, and viscosity $2.25 \mathrm{cP}$. Pigment extract from red dragon fruit skin extracted using aquadesethanol solvent has the potential to be used as natural food coloring.
\end{abstract}

Keywords: Betacyanin; Extraction; Red Dragon Fruit Peel 


\section{PENDAHULUAN}

Warna merupakan salah satu atribut mutu yang mempengaruhi penerimaan konsumen terhadap suatu produk makanan. Pewarna makanan terdiri dari dua jenis, yaitu pewarna makanan sintetik dan alami (Aberoumand, 2011). Pigmen alami berpotensi menjadi pewarna makanan alami yang tidak menimbulkan efek samping bagi kesehatan. Pigmen betasianin merupakan salah satu sumber pewarna makanan alami yang menghasilkan warna merah-violet (Sarkar et al., 2011). Pigmen ini bersifat lebih stabil pada pH 3-7 (Stintzing dan Carle, 2007). Salah satu tanaman sumber pigmen betasianin adalah buah naga merah (Hylocereus polyrhizus). Presentase kulit buah naga merah adalah 22\% dari berat buah keseluruhan (Jamilah et al., 2011). Umumnya masyarakat hanya memanfaatkan bagian daging buahnya saja, sedangkan bagian kulitnya tidak dimanfaatkan dan dibuang. Kulit buah naga merah dapat dimanfaatkan sebagai sumber bahan pewarna alami.

Pigmen betasianin bersifat hidrofilik sehingga dalam proses ekstraksinya digunakan pelarut air dan pelarut organik seperti etanol (Priatni dan Pradita, 2015; Woo et al., 2011). Selain pigmen, juga terdapat komponen lain dalam kulit buah naga merah yang ikut terekstrak dan menyebabkan viskositas ekstrak menjadi tinggi. Komponen tersebut merupakan komponen polisakarida, terutama pektin (Liaotrakoon et al., 2013). Kandungan pektin di dalam kulit buah naga merah cukup tinggi. Penggunaan pelarut aquades dalam proses ekstraksi betasianin menyebabkan komponen pektin yang bersifat larut air juga ikut terekstrak. Hal ini menyebabkan viskositas ekstrak menjadi tinggi dan berpengaruh terhadap kadar betasianin yang terekstrak. Penggunaan campuran pelarut aquades-etanol dapat secara selektif mengekstraksi pigmen betasianin sekaligus mengendapkan pektin (Naderi et al., 2012). Penelitian ini bertujuan untuk mengetahui pengaruh campuran pelarut aquades-etanol dengan rasio berbeda di dalam proses ekstraksi terhadap karakteristik ekstrak betasianin dari kulit buah naga merah.

\section{METODE}

Bahan yang digunakan dalam penelitian adalah buah naga merah yang didapatkan dari Pasar Besar Malang. Bahan kimia didapatkan dari toko kimia di Kota Malang dan Laboratorium Kimia dan Biokimia Pangan Jurusan Teknologi Hasil Pertanian, Universitas Brawijaya Malang. Alat yang digunakan dalam penelitian antara lain timbangan digital (OHAUS, Mettler Toledo), pisau, blender (National), alat pengukus, kompor, termometer, gelas ukur (Herma), erlenmeyer (Pyrex), shaker waterbath (Memmert), spatula kaca, kain saring ukuran 140 mesh, penyaring ukuran 40 mesh, dan rotary evaporator (BÜCHI Rotavapor R-205), tabung reaksi, pipet ukur, $\mathrm{pH}$ meter, spektrofotometer UV-Vis (Shimad$\mathrm{zu}$ ), color reader (Konica Minolta), viscometer (Elcometer $2300 \mathrm{RV}$ ), dan oven vakum (MMM Medcenter-VACUCELL 22).

Penelitian dilaksanakan pada bulan Oktober 2016 sampai dengan Maret 2017. Pada penelitian ini, dilakukan proses ekstraksi betasianin menggunakan campuran dua jenis pelarut dengan rasio yang berbeda. Penelitian menggunakan Rancangan Acak Kelompok (RAK) dengan satu faktor, yaitu rasio jenis pelarut. Jenis pelarut yang digunakan adalah aquades dan etanol dengan perbandingan 100:0, 80:20, 60:40, 40:60, 20:80, dan 0:100 (v/v). Tiap-tiap satuan percobaan diulang sebanyak empat kali. Parameter yang diamati meliputi kandungan betasianin (Wong dan Siow, 2015), kadar pektin (Guo et al., 2012), tingkat kecerahan/L, tingkat kemerahan $/ \mathrm{a}^{+}$, tingkat kekuningan $/ \mathrm{b}^{+}$(Yuwono dan Susanto, 2001); sudut hue (Castro-Muñoz et al., 2015), dan viskositas yang menggunakan prosedur Janiszewska (2014) dengan modifikasi. Pemilihan perlakuan terbaik berdasarkan pada kadar betasianin, nilai kemerahan $\left(\mathrm{a}^{+}\right)$, dan sudut hue tertinggi serta kadar pektin dan nilai viskositas yang rendah.

\section{Proses Ekstraksi Betasianin}

Proses ekstraksi betasianin dari kulit buah naga merah menggunakan metode Wisesa dan Widjanarko (2013) dengan modifikasi. Kulit buah naga merah dicuci terlebih dahulu untuk menghilangkan kotorankotoran. Bagian sisik kulit yang mengering dibuang. Selanjutnya dilakukan blansing uap selama lima menit (suhu $90 \pm 2^{\circ} \mathrm{C}$ ). Kulit yang telah didinginkan dihaluskan dengan blender (kecepatan tinggi, waktu satu menit). Ku- 
lit yang telah dihaluskan dicampur dengan pelarut. Rasio kulit dibanding pelarut adalah 1:5 (b/v). Proses ekstraksi dilakukan dengan menggunakan shaker waterbath (suhu 54 $\pm 1{ }^{\circ} \mathrm{C}$, waktu 26 menit, kecepatan $\left.100 \mathrm{rpm}\right)$. Setelah itu dilakukan proses penyaringan sebanyak dua kali (menggunakan kain saring ukuran 140 mesh dan penyaring ukuran 40 mesh) untuk memperoleh filtrat yang jernih. Kemudian dilakukan pemekatan menggunakan rotary evaporator (suhu $45^{\circ} \mathrm{C}$ ) hingga diperoleh volume akhir $20 \%$ volume awal.

\section{Penentuan Kandungan Betasianin}

Penentuan kandungan betasianin berdasarkan metode Wong dan Siow (2015). Sampel diencerkan dengan buffer Mcllvaine (pH 6.5) hingga nilai serapan maksimum $(1.00 \pm 0.05)$ tercapai. Buffer Mcllvaine dibuat dari asam sitrat $0.1 \mathrm{M}(30 \mathrm{ml})$ dan disodium hidrogen fosfat $/ \mathrm{Na}_{2} \mathrm{HPO}_{4} \quad 0.2 \mathrm{M}(70 \mathrm{ml})$. Apabila telah diperoleh pengenceran yang tepat, pertahankan pengenceran tersebut untuk seluruh sampel. Misal pengenceran yang diperoleh (tercapai nilai serapan maksimum $1.00 \pm 0.05$ ) adalah pengenceran 40 kali. Pada tiap-tiap sampel, $0.1 \mathrm{ml}$ sampel ditambahkan dengan $3.9 \mathrm{ml}$ buffer Mcllvaine untuk dianalisis dengan menggunakan spektrofotometer UV-Vis (UV mini-1240, Shimadzu). Pada blanko, digunakan buffer Mcllvaine sebanyak $40 \mathrm{ml}$. Kandungan betasianin dihitung dengan menggunakan Persamaan 1.

$\mathrm{BC}(\mathrm{mg} / \mathrm{L})=[(\mathrm{A} \times \mathrm{F} \times \mathrm{MW} \times 1000) /(\mathcal{C} \times \mathrm{L})] \ldots \ldots . . . .(1)$

dengan :

$\mathrm{A}=$ Nilai absorbansi pada panjang gelombang maksimum (537 nm), dikoreksi dengan absorbansi pada panjang gelombang $600 \mathrm{~nm}$ (koreksi untuk adanya pengotor)

$\mathrm{F}=$ Faktor pengenceran

MW $=$ Berat molekul betanin $(550 \mathrm{~g} / \mathrm{mol})$

$\epsilon=$ koefisien ekstingsi molar betanin $(60000$ $\mathrm{L} \mathrm{mol}^{-1} \mathrm{~cm}^{-1}$ )

$\mathrm{L}=$ panjang kuvet $(1 \mathrm{~cm})$

\section{Kadar Pektin}

Penentuan kadar pektin pada ekstrak menggunakan metode purifikasi pektin (Guo et al., 2012). Ekstrak diendapkan dengan menggunakan etanol $95 \%$. Volume etanol yang digunakan sebanyak dua kali volume ekstrak (v/v). Selanjutnya, sampel disimpan selama semalam dalam suhu $4{ }^{\circ} \mathrm{C}$.
Pektin yang telah mengalami pengendapan dipisahkan menggunakan sentrifuge dan disaring menggunakan penyaring vakum, kemudian di cuci tiga kali menggunakan etanol 95\% untuk menghilangkan monosakarida dan disakarida. Pektin yang masih basah dikeringkan pada suhu $40^{\circ} \mathrm{C}$ di dalam oven vakum sampai dicapai berat konstan, kemudian dilakukan penimbangan pada pektin yang sudah kering sesuai dengan Persamaan 2.

$\%$ pektin $(\% \mathrm{w} / \mathrm{v})=\frac{\text { berat pektin }}{\text { berat sampel }} \times 100$

Warna $(L, a, b)$

Pengukuran warna $(\mathrm{L}, \mathrm{a}, \mathrm{b})$ menggunakan metode Yuwono dan Susanto (2001). Sampel disiapkan, color reader dihidupkan, kemudian ditentukan target pembacaan $L^{*} a^{*} b$ color space pada alat color reader, lalu dilakukan pengukuran warna pada sampel tersebut.

\section{Sudut Hue}

Pengukuran sudut hue menggunakan metode (Castro-Muñoz et al., 2015). Sudut hue dihitung dengan menggunakan Persamaan 3.

$h^{\circ}=\tan ^{-1}\left(\frac{b^{*}}{a^{*}}\right)$

\section{Viskositas}

Penentuan nilai viskositas berdasarkan metode Janiszewska (2014) dengan sedikit modifikasi. Sampel diukur nilai viskositasnya menggunakan alat viscometer (Elcometer $2300 \mathrm{RV}$ ). Spindel yang digunakan adalah spindel no. 1, dengan kecepatan antara 60-200 rpm. Pengujian viskositas dilakukan pada suhu ruang. Volume sampel yang diujikan adalah $40 \mathrm{ml}$.

\section{Analisis Data}

Data dianalisis dengan menggunakan analisis keragaman/analysis of variance $($ ANOVA) dengan taraf nyata $(\alpha)=5 \%$. Apabila hasil analisis berpengaruh nyata, maka dilanjutkan dengan uji Tukey dengan taraf nyata $(\alpha)=5 \%$. Analisis data menggunakan software Minitab 16 dan Microsoft Excel 2013. 


\section{HASIL DAN PEMBAHASAN}

\section{Kadar Betasianin}

Berdasarkan hasil penelitian dapat diketahui bahwa semakin tinggi rasio pelarut etanol maka semakin tinggi pula kadar betasianin ekstrak. Akan tetapi terjadi penurunan kadar betasianin ketika rasio pelarut etanol di atas $80 \%(\mathrm{v} / \mathrm{v})$ (Gambar 1). Hal ini dikarenakan etanol merupakan zat pendehidrasi sehingga berperan dalam pengendapan pektin. Menurut Guo et al. (2016), konsentrasi alkohol yang tinggi dapat menurunkan kelarutan polimer di dalam suatu larutan. Pektin yang mengalami pengendapan terpisah dari larutan ekstrak sehingga viskositas larutan menjadi rendah. Hal ini akan mempermudah proses penyaringan. Betasianin yang bersifat larut dalam pelarut polar dapat ikut tersaring dan terpisah dari ampas.

Tujuan penggunaan pelarut aquadesetanol dalam penelitian ini adalah secara selektif mengekstraksi pigmen betasianin sekaligus mengendapkan pektin yang terkandung di dalam kulit buah. Hal ini sesuai dengan penelitian (Naderi et al., 2012) tentang ekstraksi buah naga menggunakan pelarut etanol dan pelarut aquades-etanol. Menurut Naderi et al. (2012), kandungan betasianin pada sampel yang diekstrak dengan pelarut aquades-etanol lebih tinggi daripada yang diekstrak dengan pelarut etanol.

\section{Kadar Pektin}

Peningkatan rasio pelarut etanol menyebabkan penurunan kadar pektin ekstrak (Gambar 2). Hal ini dikarenakan pelarut etanol dapat mengendapkan pektin. Pada saat proses pengendapan, akan terjadi penggumpalan pektin. Penggumpalan pektin terjadi karena adanya gangguan kestabilan terhadap dispersi koloidalnya.

Pektin merupakan polisarida yang bersifat hidrofilik dan dapat berinteraksi secara ekstensif dengan molekul air di dalam suatu larutan. Interaksi antara pektin dan air terjadi karena rantai pektin dapat membentuk ikatan hidrogen dengan molekul air. Pelarut organik seperti etanol dapat mengganggu interaksi antara pektin dengan air sehingga dapat memisahkan pektin dari larutan (Guo et al., 2016). Pektin yang menggumpal tidak ikut tersaring saat proses penyaringan sehingga kadar pektin pada ekstrak menjadi rendah.

\section{Warna $(L, a, b)$}

Perlakuan rasio aquades dengan etanol berpengaruh signifikan $(p<0.05)$ terhadap nilai kecerahan $(\mathrm{L})$, nilai kemerahan $\left(\mathrm{a}^{+}\right)$, dan nilai kekuningan $\left(\mathrm{b}^{+}\right)$ekstrak (Gambar 3$)$. Perlakuan rasio aquades dengan etanol 20:80 memiliki nilai kecerahan $(\mathrm{L})$, kemerahan $\left(\mathrm{a}^{+}\right)$, dan kekuningan $(b+)$ tertinggi. Nilai kemerahan $(\mathrm{a}+)$ tertinggi mengindikasikan bahwa kandungan pigmen betasianin di dalam ekstrak perlakuan 20:80 memiliki nilai tertinggi $(99.27 \pm 1.55 \mathrm{mg} / \mathrm{L})$. Hal ini sesuai dengan pernyataan Chranioti et al. (2015) bahwa parameter nilai kemerahan mengindikasikan pigmen betasianin yang terkandung di dalam mikrokapsul. Perlakuan rasio aquades dengan etanol 20:80 memiliki nilai kecerahan $(\mathrm{L})$ dan nilai kekuningan $(\mathrm{b}+)$ tertinggi juga. Kombinasi dari ketiga parameter tersebut $(\mathrm{L}$, $\mathrm{a}^{+}$, dan $\mathrm{b}^{+}$) pada ekstrak ini mengarah kepada warna merah-violet. Hal ini sesuai dengan pernyataan Sarkar et al. (2011) bahwa pigmen betasianin memiliki warna merah-violet.

\section{Sudut Hue}

Perlakuan rasio aquades dengan etanol berpengaruh signifikan $(p<0.05)$ terhadap nilai sudut hue ekstrak. Nilai sudut hue semakin meningkat seiring dengan meningkatnya rasio etanol (Tabel 1). Peningkatan tersebut terjadi sampai dengan rasio aquades dibanding etanol 20:80 dan kembali mengalami penurunan pada rasio 0:100. Peningkatan sudut hue mengindikasikan peningkatan derajat warna kemerahan (Castro-Muñoz et al., 2015). Warna kemerahan tersebut mengindikasikan pigmen betasianin yang terkandung di dalam ekstrak.

Tabel 1. Pengaruh rasio aquades dibanding etanol terhadap sudut hue ekstrak

\begin{tabular}{cc}
\hline $\begin{array}{c}\text { Rasio Aquades:Etanol } \\
(\mathrm{v} / \mathrm{v})\end{array}$ & Sudut Hue \\
\hline $100: 0$ & $12.32 \pm 0.46 \mathrm{c}$ \\
$80: 20$ & $12.56 \pm 0.15 \mathrm{c}$ \\
$60: 40$ & $12.00 \pm 0.26 \mathrm{c}$ \\
$40: 60$ & $14.02 \pm 0.18 \mathrm{~b}$ \\
$20: 80$ & $16.45 \pm 0.41 \mathrm{a}$ \\
$0: 100$ & $14.39 \pm 0.29 \mathrm{~b}$ \\
\hline
\end{tabular}


Jurnal Teknologi Pertanian Vol. 19 No. 3 [Desember 2018] 153-160

Pengaruh Campuran Pelarut Aquades-Etanol Terhadap Karakteristik Ekstrak Betasianin [Nurbaya dkk]

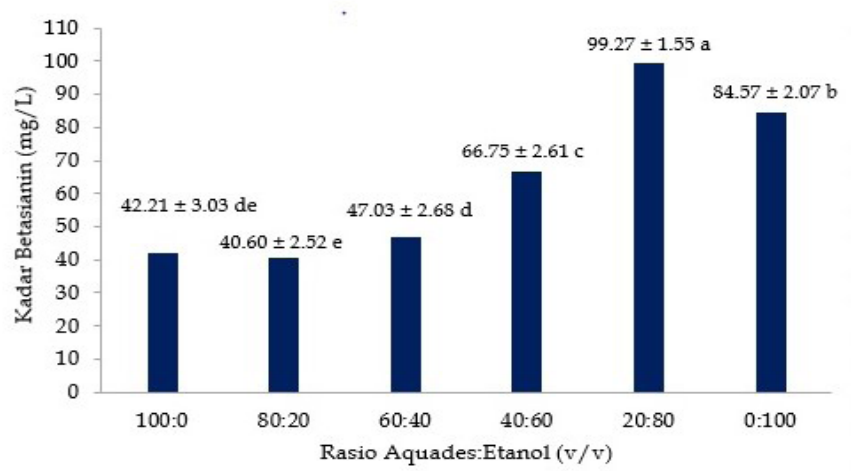

Gambar 1. Grafik kadar betasianin ekstrak dengan nilai rataan \pm standar deviasi dari empat ulangan

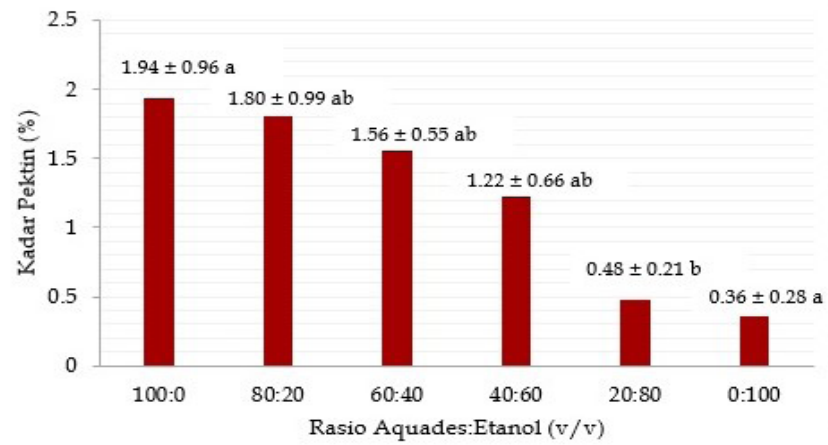

Gambar 2. Grafik kadar pektin ekstrak dengan nilai rataan \pm standar deviasi dari empat ulangan

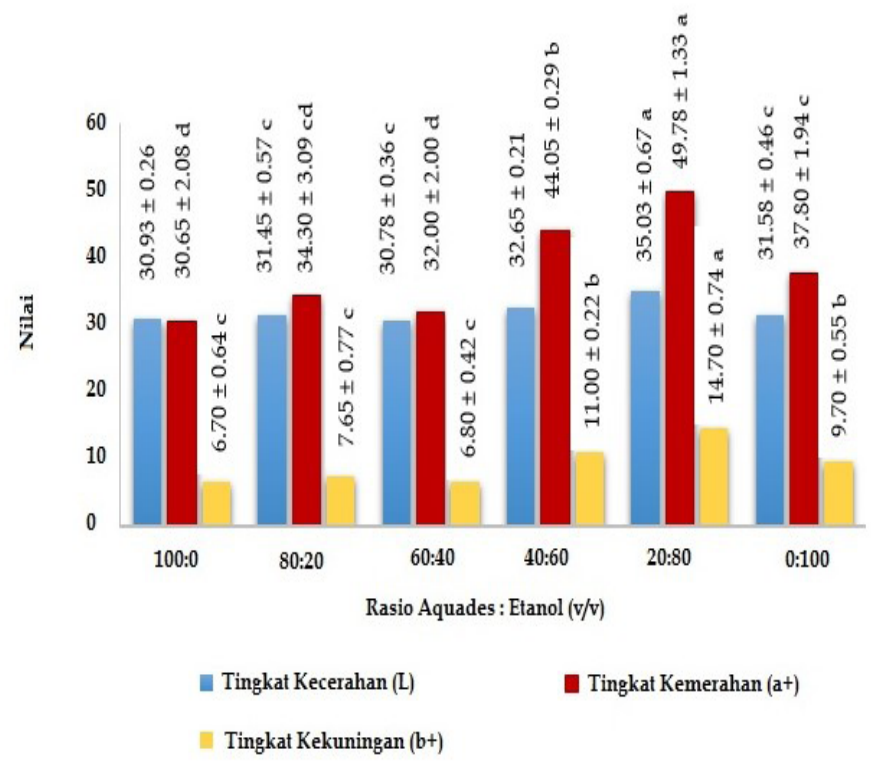

Gambar 3. Grafik tingkat kecerahan $(\mathrm{L})$, tingkat kemerahan $\left(\mathrm{a}^{+}\right)$, dan tingkat kekuningan $\left(\mathrm{b}^{+}\right)$ekstrak dengan nilai rataan \pm standar deviasi dari empat ulangan 


\section{Viskositas}

Perlakuan rasio aquades dengan etanol berpengaruh signifikan $(p<0.05)$ terhadap nilai viskositas ekstrak (Gambar 4). Nilai viskositas semakin menurun seiring dengan meningkatnya rasio etanol. Hal ini dikarenakan pelarut etanol dapat mengendapkan pektin (Castellar et al., 2006). Pektin yang mengalami penggumpalan tidak akan ikut tersaring saat proses penyaringan sehingga viskositas ekstrak menjadi rendah.

Pektin adalah polisakarida yang merupakan polimer dari asam D-galakturonat dengan ikatan a-1,4 glikosidik (Thirugnanasambandham et al., 2014). Letaknya terdapat di dalam dinding sel tanaman.

Pektin banyak terdapat di lapisan lamela tengah yang berada di antara dinding sel primer yang saling berdampingan (Thakur et al., 1997; Chan et al., 2017). Pektin bersifat dapat larut di dalam air (Naderi et al., 2012) dan memiliki karakteristik membentuk gel (Chia dan Chong, 2015). Ketika kulit buah naga merah dihaluskan, akan terjadi gaya mekanik yang menyebabkan kulit menjadi bagian-bagian yang lebih kecil. Hal tersebut menyebabkan pektin yang yang letaknya di lapisan lamela tengah menjadi keluar sehingga memproduksi slurry yang memiliki viskositas tinggi (Chia dan Chong, 2015).

\section{Perlakuan Terbaik}

Perlakuan terbaik diperoleh dari perlakuan rasio pelarut aquades dibanding etanol 20:80 (v/v) karena memiliki kadar betasianin, nilai kemerahan $(\mathrm{a}+)$, dan sudut hue tertinggi serta kadar pektin dan viskositas yang relatif rendah. Perlakuan terbaik memiliki kandungan pigmen betasianin $99.27 \mathrm{mg} / \mathrm{L}$; nilai kecerahan (L) 35.03; nilai kemerahan (a) +49.78; nilai kekuningan (b) +14.70 ; ${ }^{\circ}$ hue $14.02^{\circ}$, kadar pektin $0.48 \%$; dan viskositas $2.25 \mathrm{cP}$.

\section{SIMPULAN}

Kandungan betasianin, kadar pektin, warna $(L, a, b)$, sudut hue, dan nilai viskositas ekstrak dipengaruhi oleh rasio pelarut aquades dengan etanol. Berdasarkan hasil penelitian, rasio pelarut aquades dengan etanol 20:80 (v/v) merupakan perlakuan terbaik karena dapat menghasilkan karakteristik ekstrak yang lebih baik dibanding perlakuan lainnya. Ekstrak pada perlakuan terbaik memiliki karakteristik sebagai berikut: kandungan pigmen betasianin tertinggi (99.27 mg/L); nilai kemerahan (a) +49.78; nilai kekuningan $(\mathrm{b})+14.70$; ${ }^{\circ}$ hue $14.02^{\circ}$; nilai kecerahan (L) 35.03; kadar pektin $0.48 \%$; dan viskositas $2.25 \mathrm{cP}$.

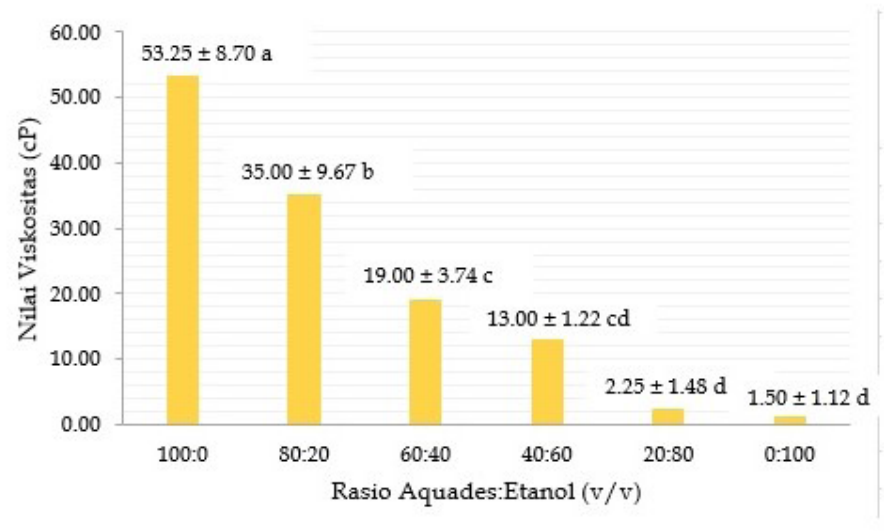

Gambar 4. Grafik nilai viskositas ekstrak dengan nilai rataan \pm standar deviasi dari empat ulangan 


\section{DAFTAR PUSTAKA}

Aberoumand, A., 2011. A review article on edible pigments properties and sources as natural biocolorants in foodstuff and food industry. World Journal of Dairy \& Food Sciences. 6, 71-78

Castellar, M.-R., Obón, J.-M., FernándezLópez, J.-A., 2006. The isolation and properties of a concentrated redpurple betacyanin food colourant from Opuntia stricta fruits. J. Sci. Food Agric. 86(1), 122-128. https://doi. org/10.1002/jsfa.2285

Castro-Muñoz, -R., Barragán-Huerta, B.E., Yáñez-Fernández, -J., 2015. Use of gelatin-maltodextrin composite as an encapsulation support for clarified juice from purple cactus pear (Opuntia stricta). LWT - Food Sci. Technol. 62(1), 242-248. https://doi.org/10.1016/j. lwt.2014.09.042

Chan, S,-Y., Choo, W.-S., Young, D,-J., Loh, $\mathrm{X},-$ J., 2017. Pectin as a rheology modifier: origin, structure, commercial production and rheology. Carbohydr. Polym. 161, 118-139. https://doi. org/10.1016/j.carbpol.2016.12.033

Chia, S,-L., Chong, G,-H., 2015. Effect of drum drying on physico-chemical characteristics of dragon fruit peel (Hylocereus polyrhizus). Int. J. Food Eng. 11(2), 285-293. https:// doi.org/10.1515/ijfe-2014-0198

Chranioti, -C., Nikoloudaki, -A., Tzia, -C., 2015. Saffron and beetroot extracts encapsulated in maltodextrin, gum Arabic, modified starch and chitosan: incorporation in a chewing gum system. Carbohydr. Polym. 127, 252-263. https:// doi.org/10.1016/j.carbpol.2015.03.049

Guo, -X., Han, -D., Xi, -H., Rao, -L., Liao, -X., Hu, -X., Wu, -J., 2012. Extraction of pectin from navel orange peel assisted by ultra-high pressure, microwave or traditional heating: a comparison. Carbohydr. Polym. 88, 441-448. https:// doi.org/10.1016/j.carbpol.2011.12.026

Guo, -X., Zhang, -T., Meng, -H., Yu, -S., 2016. Ethanol precipitation of sugar beet pectins as affected by electrostatic interactions between counter ions and pectin chains. Food Hydrocolloids. 65, 187-197. https://doi.org/10.1016/j. foodhyd.2016.11.010
Jamilah, -B., Shu, C,-E., Kharidah, -M., Dzulkifly, M.-A., Noranizan, -A., 2011. Physico-chemical characteristics of red pitaya (Hylocereus polyrhizus) peel. Int. Food Res. J. 18, 279-286

Janiszewska, -E., 2014. Microencapsulated beetroot juice as a potential source of betalain. Powder Technol. 264, 190196. https://doi.org/10.1016/j.powtec.2014.05.032

Liaotrakoon, -W., Buggenhout, S,-V., Christiaens, -S., Houben, -K., Clercq, N,-D., Dewettinck, -K., Hendrickx, M,-E., 2013. An explorative study on the cell wall polysaccharides in the pulp and peel of dragon fruits (Hylocereus spp.) Eur. Food Res. Technol. 237(3), 341-351. https:// doi.org/10.1007/s00217-013-1997-7

Naderi, -N., Ghazali, H,-M., Hussin, A,S,M., Amid, -M., Manap, M,Y,-A., 2012. Characterization and quantification of dragon fruit (Hylocereus polyrhizus) betacyanin pigments extracted by two procedures. Pertanika J. Trop. Agric. Sci. 35, 33-40

Priatni, -S., Pradita, -A., 2015. Stability study of betacyanin extract from red dragon fruit (Hylocereus Polyrhizus) peels. Procedia Chem. 16, 438-444. https://doi. org/10.1016/j.proche.2015.12.076

Sarkar, -T., Sen, M,-K., Nihar, -S., 2011. Extraction of natural pigment from beet root \& proper packaging of that red dye: a Review. J. Agric. Eng. Food Technol. 2, 116-118

Stintzing, F,-C., Carle, -R., 2007. Betalains - emerging prospects for food scientists. Trends Food Sci. Technol. 18(10), 514-525. https://doi.org/10.1016/j. tifs.2007.04.012

Thakur, B,-R., Singh, R,-K., Handa, A,-K., 1997. Chemistry and uses of pectin - a review. Crit. Rev. Food Sci. Nutr. 37(1), 47-73. https://doi. org/10.1080/10408399709527767

Thirugnanasambandham, -K., Sivakumar, -V., Prakash Maran, -J., 2014. Process optimization and analysis of microwave assisted extraction of pectin from dragon fruit peel. Carbohydr. Polym. 112, 622-626. https://doi. org/10.1016/j.carbpol.2014.06.044

Wisesa, T,-B., Widjanarko, S,-B., 2013. Penentuan nilai maksimum proses ekstraksi kulit buah naga merah (Hylocereus polyrhizus). Jurnal Pangan dan Agroindustri 2, 88-97 
Jurnal Teknologi Pertanian Vol. 19 No. 3 [Desember 2018] 153-160

Pengaruh Campuran Pelarut Aquades-Etanol Terhadap Karakteristik Ekstrak Betasianin [Nurbaya dkk]

Wong, Y,-M., Siow, L,-F., 2015. Effects of heat, $\mathrm{pH}$, antioxidant, agitation and light on betacyanin stability using red-fleshed dragon fruit (Hylocereus polyrhizus) juice and concentrate as models. J. Food Sci. Technol. 52(5), 3086-3092. https:// doi.org/10.1007/s13197-014-1362-2

Woo, K,-K., Ngou, F,-H, Ngo, L,-S, Soong, W,-K, Tang, P,-Y., 2011. Stability of betalain pigment from red dragon fruit (Hylocereus polyrhizus). Am. J. Food Technol. 6, 140-148. https://doi. org/10.3923/ajft.2011.140.148

Yuwono, S.S, Susanto, T. 2001. Pengujian Fisik Pangan. Universitas BrawijayaPress. Malang 